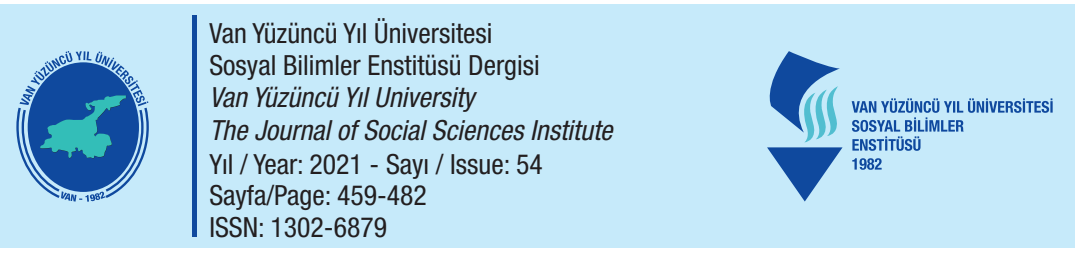

\title{
Kırklareli İlinde Serbest Cumhuriyet Fırkası: Parti Teşkilatlanması ve 1930 Belediye Seçimleri
}

The Free Republican Party in Kırklareli Province: The Party Organization and the Municipal Elections of 1930

\section{- Okan CEYLAN*}

* Öğr. Gör. Dr., Ege Üniversitesi Atatürk Illkeleri ve İnkılap Tarihi Bölümü, İzmir/Türkiye.

Instr. Dr. Ege University, Department of' Ataturks Principles and History of Turkish Revolution, İzmir /Turkey. okan.ceylan@ege.edu.tr ORCID: 0000-0001-6867-6726

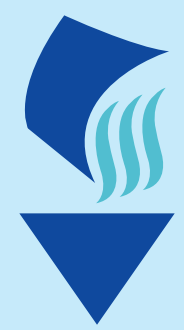

Makale Bilgisi I Article Information Makale Türü / Article Type: Araștırma Makalesi/ Research Article Geliș Tarihi / Date Received: 26/07/2021

Kabul Tarihi / Date Accepted: 21/10/2021

Yayın Tarihi / Date Published: $31 / 12 / 2021$

Atıf: Ceylan, 0. (2021). Kırklareli ilinde Serbest Cumhuriyet Firkası: Parti Teșkilatlanması ve 1930 Belediye Seçimleri. Van Yüzüncü Yıl Üniversitesi Sosyal Bilimler Enstitüsü Dergisi, $54,459-482$

Citation: Ceylan, 0. (2021). The Free Republican Party in Kırklareli Province: The Party Organization and the Municipal Elections of 1930. Van Yüzüncü YıI University the Journal of Social Sciences Institute, 54, 459-482

\section{$\ddot{\mathbf{O} z}$}

Bu çalışma Serbest Cumhuriyet Fırkası (SCF)'nın Kırklareli ilinde örgütlenme sürecini ve partinin 1930 Belediye Seçimlerindeki siyasi başarısını ele almaktadır. 1930'ların başında taşradaki gündelik yaşamın yanı sıra iktisadi ve toplumsal dinamiklerin halkın siyasi tercihleri üzerinde nasıl etkili olduğu incelemektedir. Böylece SCF'nin Edirne'deki siyasal örgütlenmesi ve 1930 yılında yerel düzeyde iktidar muhalefet ilişkileri hakkındaki literatüre katkı vermektedir. Kırklareli özelinde, Türkiye'de Tek Parti iktidarının liberal görüşlere sahip SCF ve liberalleri siyasal arenadan tasfiye etmek, devletçilik politikalarını ve Tek Parti otoritesini meşrulaştırmak olduğunu kanıtlama amacındadır. Bu bağlamda da 1930 Yerel Seçimleri yoluyla halkın iktidara olan siyasal desteğini de test ettiğini iddia etmektedir. Ancak, 1930 yılı Belediye Seçimlerinden önce Kırklareli ilinde bürokratik denetimsizliğin, ekonomik yılgınlığın ve Bulgaristan'ın savaş tehdidi görülmektedir. Kirklareli ilindeki topografyanın Trakya'nın diğer illerinin aksine daha dağlık olması ve 1929 İktisadi Buhran döneminde yaşam koşullarının daha zor olması nedeni ile Serbest Firka muhalefetinin daha kolay seçmen tabanı bulduğu ve özellikle de Kırklareli kırsalında seçim zaferi kazandığ görülmüştür. Bir diğer ifade ile, SCF'nin Kırklareli'deki siyasi başarısının toplumsal, ekonomik, siyasal ve coğrafi koşullara dayandığını belirtmektedir.

Anahtar Kelimeler: Serbest Cumhuriyet Firkası, Kirklareli, tek parti yönetimi, demokrasi. 


\begin{abstract}
This study deals with the organization process of the Free Republican Party (the FRP) in Kirklareli and the political success of the party in the Municipal Elections of 1930. In addition to daily social life in rural areas, it analyses how the economic and social dynamics were influential on the political preferences of people at the beginning of the 1930s. Thus, it contributes to the literature about the political organization of the FRP in Edirne and the relations between the government and the opposition party at the local level. It aims to prove that the Single Party Rule of Turkey liquidated the FRP that had liberal views and the liberals from the political arena and legitimate the statist policies and the single-party government specific to Kirklareli. In this context, it claims the Single Party Rule tested the political support of people using the local election of 1930. However, it seems there was a lack of bureaucratic inspection, economic frustration, and the war threat of Bulgaria before the Municipal Elections of 1930. Since the topography of Kurklareli is highland in contrast to other provinces of Thrace, and there were more difficult living conditions, it seems that the FRP could get voter base more easily and won a landslide victory in the rural parts of Kirklareli in the period of the Great Depression of 1929. In other words, it specifies that the political success of the FRP in Kırklareli depends on the social, economic, political, and geographic conditions.
\end{abstract}

Keywords: The Free Republican Party, Krrklareli, the single-party system, democracy.

\title{
Giriş
}

Serbest Cumhuriyet Firkası'nın (SCF) kuruluşu, parti programı, liberalizm ve devletçilik bağlamında dönemin sosyoekonomik koşulları üzerine hem ulusal düzeyde hem de başta Batı Anadolu olmak üzere yerel düzeyde birçok çalışma yapılmıştır. Buna karşın, 1930'larda Türkiye kırsalının coğrafi şartları ve iktisadi yapıları içinde nüfusun önemli bir bölümünü oluşturan köylülerin gündelik yaşam deneyimleri üzerinden taşrada muhalefetin doğuş sebeplerine yönelik Trakya özelindeki çalışmalar ise daha sınırlı kalmıştır. Halbuki, Kırklareli İstanbul'a oldukça yakın bir konumda bulunmakta ve İstanbul pazarlarıyla 20. yy. başlarından beri doğrudan demiryolu bağlantısına ve ticari ilişkilere sahiptir (Engin, 2008: 237). 1929 İktisadi Buhranının etkili olduğu bir dönemde yapılan 1930 Belediye Seçimlerinde, Kırklareli ilinde bulunan 7 belediyeden 4 belediyenin hangi toplumsal ve iktisadi koşullarda SCF tarafından kazanıldığ henüz yeterince aydınlatılmış değildir. Bu yüzden, SCF'nin 1930 Belediye Seçimlerinde Trakya'da en çok Kırklareli ilinde başarı göstermesi kadar bu konunun şimdiye kadar coğrafya temelinde taşradaki toplumsal ve iktisadi yapıları, halk sağlığı, yerel siyasetçiler ve sınır şehri olduğundan dış politikayı içeren disiplinler arası bir bakış 
açısıyla çalışılmamış olması Kırklareli özelinde böyle bir çalı̧̧mayı gerekli kılmıştır (Pınar, 2016: 216).

$\mathrm{Bu}$ çalışma bir yandan SCF deneyimi ile Tek Parti iktidarının gerçekleştirdiği reformlara karşı kamuoyunun tepkisini bir toplum ve siyaset mühendisliğiyle ölçmeyi hedeflediğini ve diğer yandan da 1930'ların ortamında ekonomiye devlet müdahaleciliğini ön gören Keynesci görüşlerin revaçta olduğu bir dönemde, tek parti politikalarını meşrulaştırmak için öncelikle SCF gibi liberal görüşlerin önünü kestiğini Kırklareli örneği üzerinden kanıtlama iddiasındadır. Nitekim taşrada muhalefete verilen yoğun desteğe rağmen SCF üç ay gibi kısa bir zaman içinde kapanacak ve halk iradesi de boşa çıkmış olacaktır. Tek Parti iktidarının ekonomik geri kalmışlığa yeterli çözüm üretemediği, bürokratik denetimsizliğin hâkim olduğu ve Bulgaristan tarafından tehdit altında bulunan Kırklareli ilinde, Trakya'nın diğer illerine oranla daha dağlık bir topoğrafyada ve daha zor yaşam koşullarında Serbest Fırka muhalefetinin doğuşu, gelişimi ve sona erişinin sebeplerini açıklamak hedeflenmektedir. Metodolojik olarak, toplum tabanından bir tarih okuması yöntemiyle kaleme alınan bu eser SCF'nin kuruluş nedenleri üzerine teorik bir tartışmadan yola çıkılarak coğrafi şartlar içinde Kırklareli ilinin toplumsal ve iktisadi yapısı, 1930 yılında Kırklareli ilinde yerel siyaset ve SCF'nin kuruluşu, 1930 Belediye Seçimlerinde SCF'nin başarısı ve bunun üzerine Gazi'nin 20 Aralık 1930'da Kırklareli ziyaretini ele almaktadır.

\section{Serbest Cumhuriyet Furkası Üzerine Teorik Bir Tartışma}

Türkiye'de Tek Parti yönetiminin ideolojik işaretlerinin ilk olarak 1925 yılındaki Takrir-i Sükûn Kanunu ile başladığı belirtilmektedir (Zurcher, 2000: 257). Buna karşın, Tek Parti ideolojisinin meşrulaştırılması açısından Atatürk'ün 1923 yılında verdiği bir demeç dikkat çekicidir. Atatürk, Türkiye'nin II Meşrutiyet yıllarından beri siyasi partiler arasındaki tartışmalardan çok çektiğini belirtmiștir (Karaömerlioğlu, 2006: 47). Atatürk'ün bu düşüncesinde Fransa III. Cumhuriyet Dönemi aydınları olan Emile Durkheim, Jean Jacques Rousseau ve Charles Gide gibi düşünürlerin toplumsal dayanışmayı, ahengi ve güçler birliğini öne çıkartan fikirleri bulunmaktadır (Toprak, 2020: 177- 136; Tuncay, 1999: 3). Hatta, bu fikirler halkçılık ilkesi ile de vücut bulmuştur. Karaömerlioğlu'nun ifadesiyle halkçılık ilkesi dayanışmacı bir toplum modeli öngörerek farklı düşüncelerin tartış1labileceği demokratik bir açılımın önünü kapatmıştır. Böylece toplum yaşamında çatışmadan ziyade ahenk ve uyum ön plana çıkartılarak bireysel girişimciliği ön plana çıkartan 
liberal düşünce de ikinci plana atılmıştır (Karaömerlioğlu, 2006: 47). Bu konuya dair ilk örnekleri merkezi bir ulus devletin inşası sürecinde Terakkiperver Cumhuriyet Fırkası'nın (TpCF) muhalefet deneyiminde de görmek mümkündür. Ancak, TpCF’nin aksine 1930 y1lında kurulan SCF'nin ise yapay ve Tek Parti denetiminde kontrollü bir muhalefet ya da Tuncay'ın ifadesiyle "güdümlü bir demokrasi deneyimi" olduğunu belirtmek gerekir (Tuncay, 1999: 247). Benzer bir biçimde, Koçak’a göre de SCF bir muvazaa partisidir (Koçak, 2011: 11).

Tarık Zafer Tunaya ise Tek Parti yönetimini demokrasiye aç1ımı olan "vesayet partisi" olarak tanımlamıştır (Tuncay, 1999: 3). Roger Gerard Schwartzenberg ve Maurice Duverger'in fikirlerinden hareketle, Zafer Toprak, Türkiye'deki Tek Parti idaresinin Avrupa'dakiler gibi totaliter olmadığına ve nihayetinde akılcılığ 1 ve barışı önceleyen pragmatist ve demokratik olduğuna değinmektedir (Toprak, 2004: 84-99). Ancak, Tek Parti yönetiminin SCF politikası da bu pragmatist tutumunun bir eseridir. Hatta, 1930'ların uluslararas1 konjonktüründe ve birtakım reformların hayata geçirildiği yeni bir ulus devlet inşası sürecinde muhalefetin varlığı da ancak Tek Parti iktidarının kontrolünde onun siyasetini meşrulaştırma aracıdır. Benzer pragmatist bir anlayışla Batılılar tarafından tanınan Ankara'nın Paris Büyükelçisi Fethi Okyar'ın SCF başkanlığına getirilmesi dış dünyadaki tek adamlık görüntüsünü de ortadan kaldırmak ve dış dünya (Batılı ülkeler) ile siyasi ve iktisadi ilişkileri geliştirme amacını taşıyan bilinçli bir politik hamledir (Tekeli ve İlkin, 1977: 154; Okyar ve Seydanlıoğlu, 2006: 65-101).

SCF'nin toplumsal tabanında sirasiyla liberallerin, CHF içindeki İsmet Paşa muhaliflerinin ve anti-laik bazı kimselerin olduğu görülmektedir (Çavdar, 2008: 328-331). Bu bağlamda, Serbest Fırka deneyimi, büyük çoğunluğu oluşturan bir halk kitlesinin belirleyebileceği yeni bir iktidardan ziyade Tek Parti yönetiminin 1929 Dünya İktisadi Buhranı karşısında hem muhalefetten gelen tepkileri meşru yollarla hükümet denetimindeki bir muhalefet kanalına yönlendirme hem de 1930'lardaki devletçilik politikası öncesinde liberal görüşleri tasfiye etme amacını taşımaktadır. Bunlara ek olarak, İsmet İnönü'nün anılarında SCF'nin kuruluş gerekçeleri olarak hem CHF'nin taşra teşkilatlarındaki yöneticilerin otoriter ve halktan kopuk tavırlarını dizginlemek hem de 1929 İktisadi krizi ortamında denetimsiz bir bürokratik örgüte dönüşen CHF'ye bir çeki düzen vermek ve onu güçlendirmek olduğu belirtilir. Buna karşın, iktidarın kendilerine biçtiği dar sınırlara rağmen SCF yöneticileri halktan gelen ilgi ve alaka karşısında kontrollü muhalefet anlayışının dışına çıkarak toplumun da 
desteklediği daha gerçekçi bir siyaset tarzı izlemiştir (İnönü, 1998: 110112; Pınar, 2016: 121).

Daha geniş bir açıdan ise SCF'nin kuruluşu iktisadi kriz ortamında halkın reformlara ve iktidara olan kitlesel tepkisini ölçen bir devlet politikası olarak da görülebilir Nitekim, 1930 yılında yapılan belediye seçimleri, Türkiye'de Tek Parti rejiminin kitlesel tabanının zayıflığını da ortaya koyduğundan bu durum Tek Parti yönetiminin 1930’larda köycü bir söylem geliştirmesine neden olmuştur. İktidarının meşruiyeti ve rejimin istikrarı için Tek Parti iktidarı, Cumhuriyetin ilke ve devrimleri doğrultusunda bireyler yetiştirip rejimin ilkelerini bir toplumsal mühendislik projesiyle köylülerin kalplerine ve beyinlerine yerleştirmeye çalışmıştır (Karaömerlioğlu, 1999: 67-91; Karaömerlioğlu, 1998: 56-85). Bu entelektüel fikirlerin yaşamasını sağlayan kurumsal yapılara örnek olarak köy enstitülerinin kurulduğu da göz önüne alınırsa Trakya bölgesindeki köy enstitüsü Kırklareli ilinde inşa edilecektir (Karaömerlioğlu, 2006: 52). Her ne kadar köy enstitüleri kuruluş olarak 1930'ların sonu ve 1940'lara rastlasa ve bu konunun dişında olsa da Tek Parti yönetiminin Kepirtepe Köy Enstitüsü'nü Kırklareli ili Lüleburgaz ilçesi kırsalında kurması bölgenin Trakya'nın ortasında ve demiryolları üzerinde bulunması kadar Kırklareli ilinin 1930 Belediye Seçimlerinde muhalefete verdiği desteğinde etkili olduğu yadsınamaz.

Timur'a göre SCF tüm eleştirilerini devlet kapitalizmi ve halktan kopuk Tek Parti bürokrasisi üzerine toplayarak, kentlerdeki ticaret burjuvazisi ve kırsaldaki büyük toprak burjuvazisi ile işçi sınıfı ve köylüleri peşinden sürüklemiştir. Her ne kadar bu sınıfların birbirleriyle farklı çıkar ilişkileri olsa da toplumdaki derinleşen toplumsal ve iktisadi sikıntılar bu gurupları SCF muhalefetinde bütünleştirmiştir (Timur, 1997: 176; Pınar, 2016: 129). Bu bağlamda da SCF sosyo-ekonomik açıdan farklı çıkar gurupları ile muhafazakârlar ve liberaller gibi fikri açıdan da farklı ideolojilerin ortak bir koalisyonudur. Nitekim, toplumsal açıdan, 1928 yılındaki kuraklığa bağlı düşük düzeyde kalan üretimin ardından 1929 yılında başlayan iktisadi buhran farklı toplum kesimlerinde iktisadi ve düşünsel açılardan farklı siyasi görüşlerin oluşmasına neden olmuştur (Pınar, 2016: 135). Pınar'a göre Trakya özelinde SCF'nin muhalefet tabanı 1929 iktisadi Buhranı yüzünden sıkıntı çeken tüccarlar, önemli bir bölümü ticaret ile uğraşan Yahudiler, ürünü kar etmeyen köylüler ile Rumeli'den Türkiye'ye göç etmiş muhacirler ve kimlik sorunu yaşayan Pomaklar tarafından oluşturulmuştur. Bu yönüyle de bölgedeki sosyoekonomik ve sosyo-politik bir meseleye işaret etmektedir (Pınar, 2016: 137). SCF’nin Kirklareli ilinde gördüğü yoğun desteğin temelinin 
açıklanması noktasında da tarihsel süreçte coğrafya, toplum ve iktisat gibi daha yapısal konuların irdelenmesi gereklidir.

\section{Kurklareli’nin Tarihsel Coğrafyası}

Türkiye'nin kuzeybatı köşesinde bulunan Trakya ve özelde de Kırklareli ili 1878 Osmanlı Rus Harbinden 11 Ekim 1922 tarihinde imzalanan Mudanya Mütarekesine kadar geçen yaklaşık yarım asırlık süre zarfında 1878 Osmanlı Rus Harbi’nde Ruslar tarafından, 19121913 Balkan Savaşları'nda Bulgarlar tarafından Birinci Cihan Harbinde ve Kurtuluş Savaşı'nda Yunanlılar tarafından olmak üzere dört kez işgallere, istilalara ve toplumsal yıkımlara uğramıştır. $\mathrm{Bu}$ dönemde savaşlar ve savaşların sonucunda sürekli değişen sınırlar, yaşanan zorunlu göçler, durma noktasına gelen tarımsal üretim tüm Trakya halkında hem bir geri kalmışlığa hem de gelecek endişesine neden olmuştur. Dolayısıyla Trakya'daki halkın yaşam standartları aynı zamanda Türkiye'nin Yunanistan ve Bulgaristan ile olan diş politikasıyla da yakından ilgilidir (Doğruöz, 2003: 43; Burgaç, 2017: 12-13; Aysal ve Dinçer, 2020: 235-237; Vakit, 20 Aralık 1930).

1920'lerin sonu ve 1930'ların başında Kırklareli ilinin nüfus ve iskanının önemli bir bölümü Balkanlarda meydana gelen savaşların neticesinde zorunlu göçler sonucu şekillenmiştir. 19. yüzyılın ortalarından itibaren Edirne vilayetinin bütünlük arz eden coğrafyası içinde, Edirne'ye bağlı bir sancak olan Kirklareli 1924 yılında il olmuştur (Özey, 2002: 34).

\section{Kırklareli’nin Toplumsal ve İktisadi Yapısı}

1927 Tarım Sayımına göre, Türkiye'de kırsal nüfus oranına paralel bir biçimde Kırklareli halkının \%79,3'ü köylerde yaşamakta ve tarım sektöründe istihdam olmaktadır. (DİE, 1970: 1; DİE, 1937: 5-11; Keyder ve Birtek, 2016: 306). Ayrıca, il genelinde Yıldız Dağları'nın engebeli olduğu kuzey bölgeleri, Ergene Nehri'nin geçtiği ovalardaki geniş bataklıklar ve makineleşmenin olmayışı yüzünden, il genelinde ekili alanların toplam yüz ölçümüne oranı \%8'ile sınırlı kalmıștır. 453,000 dekar arazinin \%92'sinin tahıl ekili olduğu Kurklareli ili kırsalında 75,000 dekar buğday, 94,800 dekar arpa, 63,00 dekar çavdar ve 25,000 dekar yulaf ekilidir. Kırklareli ilinin soğuk karasal iklim koşulları ve hayvancılık dolayısıyla arpa ekim alanları buğdaydan, çavdar ekim alanları da yulaftan fazladır (DİE, 1970:5; T.C Başbakanlık İstatistik Direktörlüğü, 1936: 13-28).

Ergene nehrinin geçtiği bölgelerde oluşan batakl1klar hem ovalardaki toprak ıslahını hem de sıtmanın önlenmesini gerekli kılmıştır. Bir diğer ifade ile bu bataklıklar hem tarıma engel teşkil etmiş 
hem de tarımda işgücünün kırılmasına neden olan sıtmanın kaynağı olmuştur. Örneğin, Kırklareli ilinde özellikle Midye ve İğneada kasabaları civarındaki bataklıklardan dolayı halkın çoğunluğu sıtmadan mustarip olduğu gibi dışarıdan bu bölgelere ticaret amacıyla gelenlere de sıtma bulaşmıştır. Buna karşın, bölgede sıtma için tek tedavi ise kinin kullanımıdır (Yavuz, 2018: 649-650). Ovaya yakın otlaklarda hayvan otlatan çocukların anofellere maruz kalması neticesinde sıtma daha da yayılmıştır. Trakya Umumi Müfettişi İbrahim Tali Bey'in 1934 tarihli raporunda, sıtma ele alınıp Trakya genelindeki iskân, ziraat ve sağlık alanlarına dikkat çekilmiştir (Burgaç, 2017: 137-143; Aysal ve Dinçer, 2020: 245). Ayrica, 1929 yilından itibaren Kırklareli ilinde Ergene vadisinde fenni şartlara uygun olmaksızın başlayan 1000-5000 dekar arası pirinç (çeltik) ziraatı da sıtmanın bir diğer kaynağı olmuştur (T.C Başbakanlık İstatistik Direktörlüğü, 1936: 32-33; Burgaç, 2017: 156157). Tüm bunlar, 1920 'lerin sonlarında sıtma karşısında Tek Parti yönetiminin bölgede yeteri kadar önlem alamadığını ve halkın sıkıntılarını göstermektedir.

Kırklareli ilinin kuzeydoğu bölgelerinde yer alan Midye ve Sergen nahiyelerinde ise halk ormancılık (kerestecilik) ve kömürcülük ile geçinmiştir. Bataklıkların geniş olduğu alanlarda olduğu gibi, dağlık ve ormanlık bölgelerde de halkın geçimi ve yaşam koşulları oldukça zor olmuştur. Kırklareli ormanları daha çok baltalık olup bu odunlardan odun, kömür, tütün sırığı ve bazı tarım aletleri yapılarak Trakya'nın muhtelif bölgelerine pazarlandığı görülmüștür. Buna karşın, Babaeski, Pınarhisar, Lüleburgaz ilçelerinin yüksek tarım potansiyeline sahip ilçelerdir. Kırklareli ilini İstanbul pazarlarına bağlayan demiryolları sayesinde bölgede üretilen hardaliye, şarap ve bostan meyveleri gibi bazı mahsuller İstanbul'a satılmıştır (Aysal ve Dinçel, 2020: 239-240).

Daha önceleri Lüleburgaz ve İnece kasabalarıyla sinırlı olan tütüncülük, 1923'teki Lozan Mübadelesinden sonra gelen Drama ve Selanik göçmenleriyle il geneline yayılmıştır. 1926 y1lında Alpullu Şeker Fabrikasının açılmasıyla Kırklareli ilinde tütün ve bağcıllğın yanı sıra şeker pancarı üretimi de ivme kazanmıştır (Aysal ve Dinçel, 2020: 240). 1926 yılında Alpullu Şeker Fabrikasının açılışından sonra Kırklareli çevresindeki köylerde pancar ziraatı başlamıştır. Pancar ziraatıyla birlikte çiftçilerin gelirlerinin artığ 1 bu köylerde, köy kanununun öngördüğü mektep, köy odası ve misafirhane gibi ortak kamusal yapılar hemen inşa edilmiştir. Bunun yanı sıra bu köyler Ziraat Bankası borçlarını ve vergilerini daha rahat ödemişlerdir (Burgaç, 2017: 159). Ancak, üzüm, tütün ve şekerpancarının 1929 yılındaki Dünya İktisadi Buhranında düşen fiyatları da doğrudan yöre çiftçisinin gelirini düşürmüş ve geçimi zorlaştırmıştır. 
Tarım ve hayvancılığın temel geçim kaynağı olduğu ilde tarıma dayalı sanayileşmeye örnek olarak 10 adet un fabrikası mevcuttur. Ayrıca, ağaç ürünleri, dokuma ve tarıma dayalı sanayi gelişmiştir (Aysal ve Dinçer, 2020: 240). Kırklareli kırsalındaki halk, sıtma hastalığından, yeni göçmen köylerle daha önce iskân edilen köyler arasındaki sınır anlaşmazlıklarından, tapu işlerinden, ağır vergi yükünden ve Ziraat Bankasına olan borçlarından dolayı büyük sıkıntılar yaşamıştır. (Burgaç, 2017: 24). Kırklareli köylüsü Ziraat Bankasına araba, tohum ve damızlık inek almak için borçlanırdı. (Burgaç, 2017: 95). Ancak, köylülerin arazi işlerine dair tapu sorunlarını çözmek için kasabaya veya vilayete gidip gelebilecek ne yeterli vasitaları ve yolları vardı ne de ağır aksak işleyen bürokrasi karşısında sorunlarını çözebilecek kadar zamanları mevcuttu (Burgaç, 2017: 115).

Halkın yaşadığı iktisadi sorunlara ek olarak, iki savaş aras1 dönemde, Cumhuriyetin ilk yıllarında Neuilly Antlaşması sonrası savaş çığırtkanlığı yapan Bulgarların saldırgan tehditlerine en açık yer Kırklareli olmuştur (Toprak, 2003: 66). Hatta Bulgarların sınır boylarında oluşturduğu Fond ve Apuştina adı verilen birlikler zaman zaman Kırklareli Demirköy ve İğneada civarındaki ormanlık bölgelerden Türkiye'ye sızmışlardır. Gelen Bulgar komitacılar adam kaçakçılığına bulaşmışlar ve Bulgarların Trakya'ya genişlemesi yönünde faşist propagandalar yapmışlardır. Bulgarların bu tavrı bölge basınında da Almanların Alsas Loren sorununa benzetilmiştir (Pınar, 2016: 97; Burgaç, 2017: 18-21).

Kuzeyden gelen Bulgar tehlikesi bölgede piyasalara hâkim ekonomik güç olan bazı Yahudiler tarafindan bölge halkı üzerinde yapılan propagandalar yoluyla sürekli canlı tutulmuştur. Yahudilerin bu konudaki gayeleri ise var olan iktisadi ayrıcalıklarını ve güçlerini sürdürebilmek ve Trakya iktisadında tekel oluşturabilmek içindir. Ancak, Bulgar tehlikesi karşısında yerinden edilme korkusu ve gelecek endişesi yaşayan Kırklareli halkının Yahudilerin hâkim olduğu piyasaların neticesinde sosyo-ekonomik geri kalmışlığı giderek kronik bir sorun halini almıștır. Yahudiler Trakya'daki sermayelerini, 19. yüzyılın ikinci yarısından itibaren Trakya'da yaşanan harplerin Türkler üzerinde yarattı̆̆ zenginleşmişlerdir. Buna karşın, Türkiye'de tarih yazımında Birinci Cihan Harbinden itibaren İttihat ve Terakki'nin Türkçülük hareketinin siyasette olduğu kadar iktisatta da etkisini gösterdiği anlatılmaktadır. Buna karşın Trakya'da 1934 yılına kadar yerli ve milli bir burjuva sınıfı yaratılamamış ve süreç Türklerin aleyhine işlemiştir (Burgaç, 2017: 19; Ceylan, 2021: 274-275). 
Bulgaristan ile 269 km'lik sınırın önemli bir kısmının bulunduğu ilde, halk Bulgaristan'ın izlediği psikolojik harp ile gelecek endişesine ve güvenlik zaafına kapılmışken içeride de piyasanın \%75'ine hâkim olan Yahudilerin kendi sermayelerini koruma çabalarının neden olduğu ekonomik yılgınlığa sürüklenmiştir (Burgaç, 2017: 35-37). Örneğin zahire, yapağ 1 , süt ürünleri, boyac1lık ve petrol acenteliği bölgede Yahudi iş insanlarının tekelinde olmuştur. Tüm Trakya'da olduğu gibi Kırklareli ilinde de köylüler dedelerinden kalma bir alışkanlıkla nakit sermaye ihtiyaçları için Yahudilere borçlanmışlardır. Yahudiler zahire işleriyle de uğraştıklarından tarım ürünlerini de onlara satmışlardır. Yahudilerin en ücra köylere kadar yayılmalarını sağlayan ise köyün ileri gelen aileleri olmuştur (Burgaç, 2017: 51). Toprak Mahsulleri Ofisinin henüz kurulmadığ1 1930'ların başında, Trakya'da Ziraat Bankasının zahire alım yerleri sadece Uzunköprü ve Tekirdağ bulunmaktaydı. Kırklareli'de ise alım merkezi bulunmamaktaydi. Bu da Yahudi zahirecilerin Kırklareli ilindeki tekel konumlarını arttırmıştır (Burgaç, 2017: 153).

Köylülerin yanı sıra il merkezi ve ilçelerde de bazı Yahudiler, bazı memurlara mal ve borç para vermek yoluyla kendileriyle sosyal ve ekonomik bağlar kurmuşlardır. Bu sayede de kamuya düşen işlerini kolayca yaptırmaya çalışmışlar ve müteahhit olan Yahudiler kamu ihalelerini de kolaylıkla almışlardır (Burgaç, 2017: 61-65). Hatta Kırklareli ili Pehlivanköy ilçesinde 1910 yılından beri yapılan panayırın gıda tedariki ve eğlence sektörü de uzun yıllar Yahudi iş adamları tarafından sağlanmıştır. Öyle ki İbrahim Tali Bey bu panayırların mucitlerinin Trakya Yahudileri olduğunu belirtmektedir (Burgaç, 2017: 69-73; Hürriyet, 12 Ağustos 2020).

Tüm bu yaşananlar karşısında, sınır kenti olması hasebiyle de Tek Parti iktidarının Kırklareli ve çevresinde 1934 yılında Trakya Umumi Müfettişliğinin kuruluşuna kadar bürokratik ve idari denetimsizliği mevcuttur (Burgaç, 2017: 19). Kırklareli il merkezi ve ilçelerdeki devlet memurlarının halkı azarlar tavırları ve köy muhtarlarını kendi işlerinde hizmetkar gibi kullanmaya çalıştıkları görülmüştür (Başbakanlık Cumhuriyet Arşivi [BCA] 49001728478 1; Koçak, 2006: 406). Hatta Onun Y1l Marşı'nda anayurdun demir ağlarla örüldüğü söylense de Trakya'da 20. yüzyılın son çeyreğinde inşa edilen Rumeli Demiryolları da ancak 1936 yılında Alman şirketinden devralınarak millileştirilmiştir (Engin, 2008: 235-237).

Kırklareli coğrafyasının neden olduğu ağır iktisadi ve toplumsal yaşam koşulları, 1929 Ekonomik Buhranının neden olduğu kriz ortamında, Tek Parti idaresinin bürokratik denetimsizliği ve halkın ekonomik yılgınlığ karşısında ilk toplumsal muhalefet de 1930 yılında 
SCF'nin Kırklareli'de teşkilatlanması ve 1930 yılında düzenlenen Belediye Seçimlerinde görülmüştür (Milliyet, 22 Aralık 1930).

\section{1930 Belediye Seçimleri Öncesinde Kırklareli ilinde Yerel Siyaset}

SCF'nin 12 Ağustos 1930 tarihinde kuruluşunun ardından bir hafta sonra Lüleburgaz Belediye'sinin azalarından bazıları ilçelerinde SCF'yi kurmak için Kırklareli adına ilk başvuruyu yapmışlardır (Hakimiyet-i Milliye, 22 Ağustos 1930). Hasan Tosun Bey'in SCF Trakya teşkilatını kurmakla görevlendirildiği Eylül ayının ilk haftasında kente gelip Lüleburgaz'da avukat olan Celal Bey'i görevlendirdiği bilinmektedir (Edirne Postas1, 5 Eylül 1930; Son Posta, 9 Eylül 1930). Ancak, Avukat Celal Bey (Nevrakoplu) Fethi Bey'den almış olduğu itimatname ile Kırklareli iline SCF teşkilatını kurmak üzere geldiği esnada geçtiği Lüleburgaz ve Babaeski ilçelerindeki halk üzerinde etkileyici olmuştur. Ancak Celal Bey'in Millî Mücadele dönemindeki mesafeli tavrı dolayısıyla Lüleburgaz Belediye başkanı Kemal Bey, Cerrah Nuri Bey, Avukat Ekrem ve Fehmi Beyler, Celal Bey'in adaylığına karşı çıkmışlardır (BCA, 49001728478 1; Koçak, 2006: 399). Mesleki dağılımda, SCF Lüleburgaz teşkilatı daha çok avukat ve doktorlardan oluşmuştur (Pınar, 2016: 138). Hasan Tosun Bey'in Kırklareli merkezde ise SCF Kırklareli teşkilatını kurmakla Dingiloğlu Şevket Bey ve Avukat Tahir Bey'i görevlendirdiği iddia edilmiş ancak daha sonra bu bilgi SCF tarafindan teyit edilmemiştir (Edirne Postas1, 29 Ağustos 1930; Pınar, 2016: 137).

Bunun üzerine, CHF Kurklareli milletvekili Dr. Fuat Bey de kente gelmiş, 10 gün vakit geçirdiği Kırklareli'de 1929 Dünya Ekonomik Buhranının yol açtığı toplumsal ve iktisadi koşulları yerinde görme ve halkın ihtiyaçlarını yakından inceleme firsatı bulmuştur (Edirne Postas1, 5 Eylül 1930). 10 Eylül 1930 tarihine kadar Kırklareli SCF teşkilatı kurulmuş ve ocak heyetleri de teşekkül etmiştir (Vakit, 10 Eylül 1930). Ayrıca, 22 Eylül 1930 tarihinden itibaren CHF 12. Mıntıka müfettişi Hakkı Şinasi Paşa bir hafta içinde Edirne, Kırklareli ve Tekirdağ illerini ziyaret ederek bu illerde 1930 yılı Belediye Seçimleri için partilerinin adaylarını açıklamıştır (Cumhuriyet, 22 Eylül 1930). Ancak CHF merkezi Lüleburgaz'da taşranın taleplerini ve bölgeye giden müfettişlerin görüşlerini almaksızın idare heyeti üyelerini oluşturmuştur (Pınar, 2016: 23).

Kırklareli ilindeki bürokratik denetimsizlik ve idari ilgisizlik içinde Trakya genelinde olduğu gibi belediye başkanlarının yerliler ve muhacirler arasında ayrım yapmaları, yönetim kabiliyetlerindeki noksanlar ve parti içi hizipleşmeler hem halkın mağduriyetine hem de 
CHF ye karşı halkın memnuniyetsizliğine neden olmuştur. Bu yüzden de Trakya'daki halkın toplumsal ve iktisadi sıkıntılarının çözümü için insan, sermaye ve bilgiye ihtiyaç olduğu İbrahim Tali Bey'in raporunda da belirtilecektir (Burgaç, 2017: 209). Bu dönemde, Trakya'daki CHF teşkilatlarının belirli kimselerin kontrolü altında olduğu görülmüş̧ür. CHF Trakya Bölge Müfettişi Şinasi Hakkı Bey denetimlere geldiğinde tek tek ilçelere gidip yerinde denetim yapmak yerine ilçelerden il merkezine gelen temsilcilerin verdiği bilgiler doğrultusunda rapor oluşturmuştur. $\mathrm{Bu}$ durum bir ölçüde CHF'nin politika üretmekte ve aday belirlemekte topluma ve seçmen tabanına yabancılaştığını ve halkın görüşlerini yeteri kadar önemsemediğinin de bir göstergesidir.

\section{SCF Kırklareli İI Teşkilatı}

CHF istihbarat raporlarında SCF Kırklareli teşkilat reisi Avukat Tahir Bey daha önce CHF teşkilatında görev yapmış ve halk üzerinde nüfuz sahibi olan bir siyasetçi olarak anlatılmıştır. Ragıp Bey ise zahire işiyle uğraşan, Yahudi tüccarlar ile ortaklık kurmuş ve Millî Mücadele y1llarında İngiliz Muhipleri Cemiyeti'ne üye olduğu belirtilmiştir. Daha sonra ise CHF teşkilatında bulunduğu ve Türk Ocağı üyesi olduğu da vurgulanmıştır. Manifaturacı Bezzaz Hüseyin Avni Efendi ise daha önce CHF teşkilatında bulunmuş ve yeterli nüfuzunun olmadığı söylenmiştir. Dişçi Halit Efendi de halk üzerinde nüfuzu olmayan sermaye sahibi bir kişidir. Kavaf Rasim Efendi de Drama göçmeni olup sermayedardır ve halk üzerinde çok da nüfuz sahibi değildir. Mollaoğlu Hüseyin Efendi ise koyun ticareti ile uğraşan ve köylüler tarafından tanınan bir kişidir. Zahireci Halit Efendi ise müteahhit olup var olan sermayesi ile Kırklareli kırsalındaki halk üzerinde etkili olan eski CHF üyesi bir kişidir. Kâtip Avukat Mehmet Bey de daha önce CHF üyesi olup halk nezdinde karşıllğı olan bir siyasetçidir. Veznedar Mollaoğlu Mehmet Bey de ildeki entelektüel kesimden ziyade avam kesimi üzerinde etkili olan bir kişidir. Molla Yusuf Efendi ise muhacir olup CHF aleyhtarı olan bir kişidir. Süleyman Çavuşoğlu Hasan Efendi ve Şükrü Efendi SCF propagandasından sorumlu bir kişidir. Mandıracı Şapat da propaganda işlerinden sorumlu olup aslen Musevi'dir. Millî Mücadele döneminde İngiliz Muhipleri Cemiyeti'ne üye olmuştur. Kardeşlerinin asker kaçağ 1 olup Yunanistan'a kaçtıkları belirtilmiştir. Milyonzade Hasan Ağa ve Müezzin Kazım Efendi ise halk üzerinde nüfuzları olmayıp şapka kanununa muhalefeti ile bilinen kişilerdir (Pınar, 2016: 147-148). Dolayısıyla, SCF teşkilatları anlatılırken raporda bu kimselerin Millî Mücadele yıllarındaki konumlarına dikkat çekildiği görülmektedir. 
Vize'de SCF teşkilatı için parti Doktor Kemal Bey'i görevlendirmiş̧tir. Hatta SCF Vize ilçe teşkilatı ağırlıklı olarak tüccar ve müteşebbis kesimlerden oluşmuştur (Pınar, 2016: 138). Vize ilçesi özelinde kaza heyeti temsilen Hacı Münir Bey'in dürüst kişiliğine rağmen parti teşkilatlanmasında başarılı olamadığı ve SCF teşkilatının Vize'de kuruluşu ile CHF'nin zor durumda kaldığ 1 belirtilmiştir. Münir Bey'in başında bulunduğu CHF heyeti ilçede hiçbir siyasi faaliyet göstermemiş ve kongrelerin yapıldığını kâğıt üzerinde göstermiş̧lerdir. SCF'nin Vize'de iki köy hariç tüm köyler SCF'yi desteklemiştir (BCA 49001728478 1; Koçak, 2006: 404) İlçe kaymakamı da Vize ilçe ve köylerinde SCF'ye yoğun katılımların olduğunu ve CHF'den istifaların yoğunlaştığını belirtmiştir (Pınar, 2016: 25). Vize'de SCF'nin kısa zamanda toplumsal taban bulması CHF teşkilatlarının rehaveti olduğu kadar ilçenin dağlık ve ormanlık olan coğrafyası ile de ilgilidir. Nitekim Vize iktisadi açıdan Kırklareli ilinin diğer ilçelerine oranla daha geri kalmış bir ilçedir. Ormancılıkla geçinmeye çalışan Vize halkı fakir olmasına rağmen ormancılık faaliyetleri ticari faaliyet gibi görülerek kendilerinden kazanç vergisi alınmıştır. Ağır vergi yükü ilçe halkının Tek Parti yönetimine küsmesine ve SCF'yi desteklemelerine yol açmıştır (BCA 49001728478 1; Koçak, 2006: 404).

Vize Ocak teşkilatlanması 22 Eylül 1930'da tamamlanmıştır. Burada dikkat çeken nokta ise göçmen kesimin önde gelen isimlerinin ağırlıklı olarak bulunmasıdır. Ocak reisi Doktor Kemal Bey CHF raporlarına göre Tıbbiye mezunudur. Kâtip Kemal Ziya Bey Yüksek Ticaret Mektebi mezunu olup Ziraat Odası Başkanlığı görevinde bulunmuş ve çeltik (pirinç) ticareti ile uğraştığı belirtilmektedir. Muhasebeci Tahsin Bey ise Vodina göçmeni olup yerli halka karşı göçmenleri savunan ve bu yüzden de memurlarla karşı karşıya gelen bir kimsedir. Üyeler ise Raşit Efendi, Esat Efendi, Fen Memuru Celal Bey, Yaşar Ağa, Çögenlili Said Ağa, İzzet Ağa ve Yusuf Çavuş’tan oluşmaktadır. $\mathrm{Bu}$ üyelerin hepsi muhacirler ve köylüler üzerinde bir nüfuz sahibi olmakla birlikte Said Ağa çiftçi, Celal Bey memur ve diğerleri de daha çok ticaret ile uğraşmaktadır (Pınar, 2016: 154-155).

Pınarhisar ilçesi SCF teşkilat reisi Demiroğlu İbrahim Efendi'dir. CHF raporlarına göre, aslen Boyran göçmenlerinden olup bakkal esnaflığı yapan İbrahim Efendi'nin eskiden CHF'li olduğu ve SCF'ye geçiş nedeninin yerel siyasetteki iktisadi çıkar ilişkilerine dayandığı belirtilmektedir. Kâtip Mustafaoğlu Ahmet ise halk üzerinde bir nüfuzu olmasa da ilçenin aydın gençlerindendir. Üyelerden Alioğlu Tevfik Efendi hem eski bir belediye meclis üyeliği hem de muhtarlık görevinde bulunmuştur. Hamdioğlu Ethem Ağa ise çiftçi olup doğrudan siyasette bulunmamıştır. Kendisinin muhtarlığa aday olmayı 
düşündüğü için SCF'ye girdiği belirtilmiştir. Son olarak da Katipoğlu Ahmet Efendi bulunmaktadır. Pınarhisarda CHF teşkilatının iyi çalışmamasının yanı sıra bir önceki muhtarlık seçiminde özellikle göçmen kesimin güvenini kazanmıș göçmenlerin önde gelenlerinden biri olan Memiş Efendi'ye yapılan haksızlık gündemde tutulmuştur. Memiş Efendi seçimde 200 oy almasına rağmen CHF'nin baskısı sonucu sadece 13 oy alan diğer adayın muhtar yapılması yüzünden Memiş Efendi SCF'ye geçmiş ve seçimi SCF kazanmıştır (Pınar, 2016: 153).

Babaeski SCF ilçe teşkilatı ise CHF raporlarında Başkan Hamdi Bey'in Üsküplü ve Boşnak olduğunu Balkan Savaşlarından sonra Babaeski'ye yerleştiğini ve Pomaklar üzerinde etkili olduğunu belirtmektedir. Kâtip Tahsin Efendi hakkında da Çerkez asıllı olduğu ve mahkeme başkatipliğinden istifa ederek SCF'ye katıldığı belirtilmektedir. Veznedar Yakup Naci Efendi'nin ise Trablusgarp'ta komiser yardımcılığ1 yaptı̆̆ ve Balkan Savaşlarından sonra Babaeski'ye yerleştiği belirtilmektedir. Boşnak Ferit Efendi ise Babaeski Savcısı Necati Bey'in eniştesidir. Ayrıca Tahir Efendi, emekli maliye memuru Saadetin Efendi ve Bulgaristan göçmeni Bedreli Mehmet Ağa'dan oluşmaktadır. Göçmen nüfusun az olması nedeniyle Babaeski SCF teşkilatının aslında en zayıf olduğu yerdir (Pınar, 2016: 156-157). Dolayısıyla SCF teşkilatlarının örgütlenmesinde taşranın önde gelen kişilerin toplum üzerindeki nüfuzları, şahsi ekonomik çıkarları ve temsil ettikleri toplumsal sınıflar (göçmenlik) gibi faktörler etkili olmuştur.

Kırklareli ilinde SCF'nin toplumsal tabanının oluşumunda Tek Parti bürokrasisinin halktan kopuk olması, hükümetin idari denetimsizliği, Bulgar tehlikesi karşısında yaşanan emniyet ve güvenlik sorunu, 1929 Dünya Ekonomik Buhranının yarattı̆̆ iktisadi kriz ortamı, ağır vergilendirmeler ve muhacirlerin iskân sorunları etkili olmuştur. Bir diğer ifade ile SCF'nin Kırklareli'deki başarısı rejim karşıtlığından ziyade aslında hükümetin ve yerel idarecilerin başarısız siyasetlerine halk tabanından gelen demokratik bir muhalefetin neticesiydi (Hürriyet, 23 Aralık 2005). SCF Trakya'daki seçimlerde vergilerin hafifletileceği, inhisarların kaldırılacağı ve tekelleşmenin önüne geçileceğini belirterek Mustafa Kemal Paşa'nın da kendileriyle birlikte hareket ettiği yönünde propagandalar yapmışlardır (Pınar, 2016: 178).

Türkiye ölçeğinde de CHF ve SCF parti programları arasındaki dört temel fark yabancı sermeye, demiryolları, devletçilik ve ticaret burjuvazisini vergilendirme konularına olan farklı yaklaşımlarıdır (Ivanova, 1978: 21). CHF, temelinde sağlam para, denk bütçe ve sık1 
bir mali disiplin olan daha korumacı ve devletçi bir iktisat politikası izlerken SCF ise daha liberaldir (Pamuk, 2015: 191).

\section{1930 Kırklareli Belediye Seçimleri}

1930 Belediye Seçimleri Edirne'de olduğu gibi Kırklareli'de de ekim ayının başında başlamış ve 22 Ekim tarihine kadar tamamlanmıştır (Cumhuriyet, 22 Ekim 1930). Hatta Kırklarelili kadınlar da bu seçimlerde oy kullanmaları sebebiyle seçimlerde CHF ya da SCF lehine propagandalar yapmışlardır. Örneğin Fevziye Şevket Hanım CHF lehine çalışmış ve başarılar elde etmiştir (Vakit, 11 Ekim 1930). Birçok Avrupa ülkesinden bile önce Türk kadınlarının seçimlerde oy kullanmaları Türk demokrasi tarihi açısından olumlu bir hukuki ve siyasi gelişme olsa da seçimlerde bazı bürokratlarında karıştığı usulsüzlükler, baskı ve şiddet ortamı seçim güvenliğine gölge düşürmüştür. Örneğin, Yeşilyurt Gazetesi yazarlarından Tevfik Abdurrahman Bey gazetedeki köşesinde, Kırklareli Belediye seçimlerinde halkın polis ve jandarma baskısına rağmen oylarını, hakları, hürriyetleri ve vicdanlarının sesi doğrultusunda verdiklerini yazmıştır. Bu uğurda seçimlerin yapıldı̆̆ı belediye binasının önünde günlerce aç ve susuz bekleyen halk kitlelerinin temiz ve metin demokrasi ruhlarının tüm memleketin tezahürü olduğunu da belirtmiştir (Edirne Postası, 6 Kasım 1930). Baskı ve şiddete bir başka örnek, Hamidiye Mahallesinden bir kişinin Kırklareli eski belediye başkanı, CHF il başkanı ve belediye baytarı tarafından öncelikle kendisine CHF'ye oy vermesi karşılığında teklif edilen 50 lirayı almadığı ve de partiye destek vermediği gerekçesiyle CHF Kırklareli binasında dövülmesidir (Edirne Postas1, 17 Ekim 1930). CHF binasından yükselen "can kurtaran yok mu” sesleri üzerine sokaktaki kalabalığın hücumu karşısında kavgaya karışan partililer olay yerinden kaçmıştır. Ancak, olay emniyete intikal etmiştir (Son Posta, 21 Ekim 1930). Ayrıca SCF'ye oy vermesi muhtemel 1200 kişinin Kırklareli ilinde sandığa gitmesinin engellenmesi karşısında CHF Lüleburgaz teşkilatından dahi istifalar yaşanmıştır (Pınar, 2016: 187).

Krrklareli milletvekillerinden Fuat ve Şevket Beylerin kente gelmesinden sonra seçimlerde usulsüzlüklerin, tutuklamaların ve kargaşanın arttığı iddia edilmiştir (Pınar, 2016: 203). Tüm bunlara rağmen, Kırklareli'nin üst düzey bürokratlarına göre halk iktisadi krizden etkilenmiş olsa da SCF adaylarının seçimleri kazanabilecek siyasi gücü yoktu. Ancak, CHF'nin toplum tabanındaki karşılığı yeterli olmadığından olacak ki Kirklareli milletvekillerinden bazıları CHF teşkilatındaki gençlerle Roman mahallelerine giderek erzak ve para dağıttıkları yönünde birtakım iddialar da ortaya atılmıştır (Pınar, 2016: 
185-186). Ayrıca, Edirne'de olduğu gibi Kırklareli ilinde de SCF ye oy verecek olan yurttaşlara sandık başında tarafsız olması gereken görevli memurların, taraflı davranarak zorluk çıkartmaları halkta derin bir üzüntüye neden olmuştur. Bunun üzerine Kırklareli Valiliği'ne ve Cumhuriyet Savcılığı'na suç duyuruları yapılmıştır (Son Posta, 7 Ekim 1930).

O güne kadar diğer seçimlere çok da ilgi göstermeyen Kırklareli Yahudilerinin çoğunluğu bu seçimde SCF'yi desteklemiştir (Vakit, 7 Ekim 1930). Bu durum, CHF'nin milliyetçilik ve özellikle de Yahudilerin Trakya'da tekelleşmesini engelleyebilecek devletçilik ilkesine karşı duruşlarının ilk işaretleridir (Pınar, 2016: 54). Hatta, Edirne Bulgar Konsolosluğu tarafından Bulgaristan Dış İşleri Bakanlığı'na 20 Ekim 1930 tarihinde gönderilen raporda Edirne ve diğer tüm Trakya kentlerinde seçimlerin 17 gün kadar sürdüğü, bask1 altında geçtiği ve seçim usulsüzlüklerinin yapıldığı bildirilmiştir. Örneğin Kirişhane, Kıyık, Yıldırım ve Karaağaç gibi semtlerde geceleri dolaşan suça meyilli kişilerin bağırışları yüzünden muhalifler evlerinden kapı dışarı çıkamamakta ve halkın oylarını da Belediye Başkanlığı binalarında polis gözetiminde açık oy şeklinde verdiği ifade edilmiştir. Ayrıca, muhalefet adaylarının şehrin en bilinen ve en saygın kişilerinden olduğu ve içlerinde çok sayıda iş adamları, doktorlar ve avukatlar olduğu belirtilmiştir. Hatta, bazı Musevilerin de SCF'den aday gösterildiği için konsolosa gelen istihbarata göre Trakya Yahudileri SCF'nin seçim kampanyası için 7000 lira harcamışlardır. Raporda, Trakya halkının İsmet Paşa yönetimindeki Tek Parti'den hiç memnun olmadığı Trakya'nın geri kalmışlığından Tek Parti İktidarının köylerle hiç ilgilenmediği için buralarda altyapı, sağlık ve eğitim hizmetlerinin yetersizliği de dile getirilmiștir. Ağır vergi yükünden kaynaklı toplumsal ve iktisadi sıkıntıların olduğu ve vergisini ödeyemeyen bazı yurttaşların hapis cezası aldıklarını belirterek halkın iktidarın değişmesinin istediği ve halkta yeni iktidarın ekonomiyi iyileştirmesi temennileri olduğu raporda belirtilmiştir (Ivanova, 1978: 27-28). Ayrıca Kırklareli ilinde 180 Yahudi'nin partinin ilk kuruluş günlerinde SCF'ye üye oldukları bilinmektedir. Bu durum karşısında CHF daha çok milli söylemlerde bulunmaya başlamıştır (Pınar, 2016: 150-178). 1929 Dünya Ekonomik Buhranı neticesinde halkın yaşadığı sıkıntılar bir yandan CHF'nin Kırklareli ve Trakya' daki nüfuzunu zaafa uğratırken diğer taraftan da Tek Partinin Trakya teşkilatları siyasi menfaatler peşinde koşan taşradaki belirli aileler arasındaki kavgalara sahne olmuştur (Pınar, 2016: 21-22).

1930 y1lındaki belediye seçimlerinde Kırklareli iline bağlı Lüleburgaz ilçesinde SCF oyların 1989'unu alırken CHF ise 1320 oyda 
kalmıştır. Pınarhisar ilçesinde ise SCF oyların 714'ünü alırken CHF 42 oy almıştır. Dolayısıyla Lüleburgaz ve Pınarhisar belediyelerini SCF kazanmıştır (Edirne Postası, 14 Ekim 1930). Lüleburgaz ve Pınarhisar'ın yanı sıra Vize ve Üsküp belediyelerini de SCF kazanmıştır (Koçak, 2006: 339-340). Dolayısıyla Kırklareli ilinin güneydoğu bölgesi tamamen SCF tarafından kazanılmıştır.

Şevket Ödül'ün kaleme aldığ 18 Ocak 1931 tarihli teşkilat raporu 1929 y1lındaki Dünya Ekonomik Buhranından sonra Kırklareli ilindeki toplumsal ve iktisadi yaşamı mercek altına almakta ve il genelinde faaliyet gösteren CHF ve SCF teşkilatları hakkında bilgiler vermektedir. Buna göre, Kırklareli Belediye seçimlerini SCF adayı Ekrem Rıfat Bey'in kazanacağına yönelik beklentilerin olduğu vurgulanmıştır (Cumhuriyet, 23 Eylül 1930). Raporda Kırklareli ilinde bulunan 7 belediyenin 4'ü SCF tarafından kazanıldığı hatta Kırklareli belediyesinin CHF tarafindan sadece 80 oy farkla kazanıldığının da altı çizilmiştir (Cumhuriyet, 17 Ekim 1930; BCA 490: 01728478 1; Koçak, 2006: 397-398). Hatta çok ilginçtir ki Nevrakoplu Av. Celal Bey'ın 1srarı üzerine CHF İl Başkanı Tahir Bey SCF'den Belediye Başkan adayı olmuştur. Seçimi normalde SCF adayının kazandığı ama seçime usulsüzlükler karıştırıldığı konusunda şaibeler de dolaşmıştır. Nitekim, Trakya Paşaeli Müdafai Hukuk Cemiyeti yöneticilerinden olan Dingiloğlu Şevket Bey 1930 seçimlerinde CHF'den Kırklareli Belediye Başkanı seçilmiştir (Mazlum, 2020: 65).

Pınarhisar ve Vize'de ise belediyeleri \%90'na yakın bir oy alan SCF Üsküp'te \%72 ile seçimi kazanırken Lüleburgaz'da ise sadece 170 oy farkla kazanmıştır (Pınar, 2016: 216). Bu konu da SCF teşkilatının Kırklareli kırsalında çok iyi örgütlendiği, halk nazarında güven kazandığ 1 ve CHF teşkilatına oranla daha uyumlu hareket ettiği belirtilmiştir (BCA, 490/01-728-478-1; Koçak, 2006: 397-398). Nitekim CHF Kırklareli İdare Heyeti arasında geçimsizlik olduğundan belediye reisi Kara Hafizoğlu Hüseyin Bey'in CHF Fırka Müfettişliği tarafından değiştirilmesi talep edilmiştir. Hatta parti içi bölünme o kadar büyüktür ki belediye seçim namzetleri dahi tespit edilememiştir (BCA 49001728478 1; Koçak, 2006: 399).

\section{Kırklareli İlinde SCF' nin Siyasi Başarısı}

Toplumsal düzeyde SCF teşkilatının hızlı yayılmasında CHF içindeki bölünmeler, ihtiraslar ve menfaat çatışmaları, 1929 Dünya Ekonomik Buhranının yarattığı iktisadi sıkıntılar ve 1878 Osmanlı Rus Harbinden beri Kurklareli iline yerleşen muhacirlerin iskân işlerinde yaşadıkları bürokratik sıkıntıların etkili olduğundan bahsetmiştik. Kırklareli Üsküp’te bu sıkıntılardan mağdur olan köylüler, köydeki 
önde gelen bazı kişilerin söylediklerine riayet edip SCF'nin başarılı olduğu takdirde her derde deva olacağını düşünmüşlerdir (BCA 49001 728478 1; Koçak, 2006: 400). Örneğin, Kırklareli ve Trakya genelinde herhangi bir irticai faaliyet görülmez ve halk Cumhuriyetin ilke ve devrimlerine bağlıyken Alpullu Şeker Fabrikasında bazı Yahudiler tarafından desteklenen komünist bir örgütlenmenin olduğu iddiaları da ortaya atılmıştır (Burgaç, 2017: 79). Hatta Yahudiler Bulgarların propagandalarını pancar ziraatı konusunda da özellikle Pomak köylerinde yaymaya çalışmışlardır. Bazı Yahudi tüccarlar eski Bulgarca (Pomakça) konuşan Pomaklara Bulgaristan'ın daha yüksek fiyatlardan pancar almak istediğini ama buna Tek Parti yönetiminin izin vermediğini belirtmişledir. Yahudilerin asıl sıkıntısı ise Alpullu Şeker Fabrikasının açılışı dolayısıyla şeker piyasasındaki tekellerini kaybetme sorunlarıdır (Pınar, 2016: 99).

SCF'nin Kırklareli kırsalındaki taşra teşkilatlarından Üsküp kazası incelendiğinde halkın çoğunluğunun göçmen ve Pomaklardan olduğu ve çiftçilikle uğraştıkları görülmektedir. Dolayısıyla SCF teşkilatında bulunan kişilerin de bunlarla sosyal ve iktisadi bağlantıların olduğu görülmektedir. CHF raporlarına göre Üsküp SCF teşkilat reisi Raşit Efendi eski bir CHF üyesi olup ilçesinde hayvancılıkla uğraşan Pomakların sütlerini pazarlama ve komisyonculuk işleriyle uğraşmaktadır. Üyelerden Salihoğlu Küçük Abbas ise koyun tüccarı olup hiçbir siyasi görüşünün olmadığı ve belediye reisiyle birlikte hareket ettikleri belirtilmiştir. Abdullahoğlu Bakkal Sarnan da sermayedardır. Mehdioğlu Hüseyin Çavuş da muhtar olup 1929 yılında CHF Üsküp teşkilat reisliği görevinde bulunmuştur. Hüseyinoğlu Ahmet Hoca eski CHF'li olup dindar bir kişidir. Mehmetoğlu Hüseyin Bey de halk nezdinde itibarı olan ama siyaseten sabırsız bir kişilik olarak belirtilmiştir (Pınar, 2016: 152).

Pınarhisar'da CHF muhtarlık seçimlerinde 200 oy alan aday yerine 13 oy alan adayı muhtar yaptığından Pınarhisar halkının tepkisi ile karşılaşmıştır. Neticede kasaba halkı SCF'yi desteklemişlerdir. Pınarhisar, Vize ve Üsküp Kırklareli taşrasının toplumsal ve iktisadi özelliklerini yansitırken Lüleburgaz ise daha merkezi bir ilçedir. Müdafa-i Hukuk Teşkilatına büyük destek vermiş olan ilçede 1926 Belediye seçimlerinden beri CHF etrafında halk ikiye bölünmüştür. Lüleburgaz Belediye reisi Kemal Bey zeki ve vizyoner bir siyasetçi olsa da hırslı biri olarak tarif edilmiştir. Buna karşın Cerrah Nuri Bey ise köylüler üzerinde iktisadi gücü olan bir kişi olarak anlatılmıştır (BCA 49001728478 1; Koçak, 2006: 403).

Ayrıca Türk Ocağı Başkanı Rüstem Bey ile Ziraat Odası Başkanı Süleyman Bey Lüleburgaz'da SCF teşkilatının kuruluşunda rol 
oynamışlardır (Pınar, 2016: 151). Lüleburgaz'da ve Kırklareli genelinde SCF teşkilatlarının desteklenmesinde parti hizipçilik, bölünmeler ve taşranın önde siyasetçilerinin halk üzerindeki nüfuzları seçimlerde etkili olmuştur. Bu yüzden de Cerrah Nuri Bey'in halkı örgütleme gücünden çekinen CHF onu SCF'den istifaya zorlamıştır.

Babaeski ilçesinde ise göçmen nüfusun az olmasından dolayı halkın bürokrasi kaynaklı sıkıntıları daha azdır. Buna karşın göçmen Pomak nüfusa sahip olan Mandıra, Katranca ve Kuştepe'deki halk toplumsal ve iktisadi sıkıntılardan şikayetçiydi. Ayrıca Trakya'da CHF teşkilatlarının da rehaveti karşısında 1929 Ekonomik Buhranının köylüler üzerinde neden olduğu yoksulluk küresel bir krizin etkilerinden ziyade daha çok Tek Parti yönetiminin ekonomi politikalarındaki başarısızlığına bağlanmaktaydı. Nitekim Kırklareli köylüsü yol vergisinden, hayvan vergisinden ve orman köylerinden alınan kazanç vergisinden çok mağduriyetler yaşamıştır. Atatürk, Kırklareli halkı nezdinde partiler üstü bir konumda görüldüğünden, Kırklareli ilinde SCF toplumsal tabanını inşa ederken Atatürk'ün kız kardeşi Makbule Hanım'ın da partilerinde bulunduğu propagandasını sık sık yapmıştır (BCA 49001728478 1; Koçak, 2006: 404-405).

Ayrıca, 1930'lu yıllarda Trakya'nın en önemli endüstri bitkilerinin şekerpancar1, susam ve tütün olduğu düşünülürse 1929 Ekonomik Buhranı kırsal alanları sınırlı da olsa pazara açan bu ürünler üzerinde yarattığı fiyat düşüşlerinin çiftçileri olumsuz yönde etkilediğini belirtmiştik. SCF adayları Kırklareli kırsalında tütünlerinin ucuza satıldığından şikayetçi olan köylülere CHP'li milletvekillerinin tütün komisyonculuğu yaptıkları yönünde menfi propagandalar da yapmışlardır (BCA 49001728478 1; Koçak, 2006: 406).

SCF'nin yereldeki kazanımlarına rağmen, bu parti Türk siyasetinde 12 Ağustos-17 Kasım 1930 tarihi arasında yalnızca 95 gün yaşayabilmiştir. Fethi Bey’in partisini feshetmesinden iki gün önce yapmış olduğu meclis konuşmasında belediye seçimlerinde yoğun usulsüzlüklerin, müdahalelerin ve fesatlıkların yaşandığı 22 il arasında Kırklareli ilini de zikrettiği görülmektedir (TBMM ZC 15 Kasım 1930). Neticede Mecliste vuku bulan hararetli tartışmaların sonucunda Fethi Bey Gazi’yi ziyaret etmiş ve istifasını sunmuş ve parti kapanmıştır (Edirne Millî Gazete, 18 Kasım 1930). Seçimlerde her ne kadar Kırklareli ilinde dört belediye muhalefet tarafindan kazanılsa da SCF'nin kapatılmasından sonra halkın desteği boşa çıkmış ve Tek Parti yönetimi bir ölçüde il genelinde halkın nabzını ölçmüş, partilerinin kapatılmasının ardından devletçilik öncesi liberaller siyasetten tasfiye edilmiş ve Kırklareli'nde 1930'larda nasıl bir politika izlemesi gerektiğini ön görmüştür. Tüm bunları ve halkın muhalefete olan 
teveccühünü yerinde görmek üzere Atatürk'ün kısa süren bir Kırklareli ziyareti de olmuştur.

\section{Seçimlerin Ardından Gazi'nin Kırklareli Ziyareti}

Kırklareli ilinde SCF 'nin başarısı üzerine Gazi 21 Aralık 1930 tarihinde Kırklareli ilini ziyaret etmiştir. İlk gezisini Alpullu Şeker Fabrikasına yapan Atatürk, fabrikadaki şeker üretiminden duyduğu memnuniyeti ifade ederek oradan ayrılmıştır (Cumhuriyet, 22 Aralık 1930). Hatta, Türkiye'de pancar üretiminin arttırılması ve şeker endüstrisinin geliştirilmesine yönelik atılımın 1923 y1lında düzenlenen İzmir İktisat Kongresinde kararlaştırıldığı bilinmektedir (Mazlum, 2020: 53). Gazi Mustafa Kemal Atatürk Alpullu'ya geldiğinde Millî Mücadele döneminin Edirne Valisi görevinde bulunan İktisat Bakanı Şakir Kesebir, Kirklareli Milletvekili Fuat Umay, Kirklareli Milletvekili Şevket Ödül ve Edirne Milletvekili Faik Bey ile Kırklareli Valisi Mustafa Arif Bey, Belediye Başkanı Şevket Dingiloğlu Gazi'yi karşılaşmışlardır. Alpullu'dan Kırklareli iline trenle gelen Atatürk'ü büyük bir halk kitlesi coşkuyla karşılamıştır. Atatürk'ün yanında İçişleri Bakanı Şükrü Kaya, Halk Fırkası Genel Sekreteri Recep Peker, Ali Çetinkaya, Kılıç Ali, Tevfik Rüştü Aras, tarihçi Afet İnan, Ruşen Eşref, Hasan Riza Soyak, yaveri Nasuhi Bey ve General Fahrettin Altay gibi dönemin önemli isimleri de bulunmaktaydı. Mustafa Kemal Atatürk'ü Kırklareli heyetinden ise karşılayanlar arasında Gazeteci Ali Rıza Dursunkaya, Türk Ocağı Başkanı Kara Hafiz'ın Mehmet ve Öğretmen Kazım Konuralp, Baytar Süreyya, Kırklareli Fırka Komutanı Mürsel Paşa, Makbule Süreyya, Şükriye Rahmi, Mehmet kızı Hayriye Hanım, Kavaf Emin, Kağıtçı Ahmet, Avukat Nuri Bey, Ahmet Ziya Çetintaş bulunmuştur (Görünüm, 21 Aralık 2017; Vakit, 20 Aralık 1930; Milliyet, 20 Aralık 1930).

Atatürk, Kırklareli ilinde bulunan ordu kumandanllğı ve belediye ziyaretinde belediye azalariyla memleket meselelerini görüştükten sonra da CHF teşkilatına gelerek burada her kesimden halkın mümessilleriyle görüşmüştür (Cumhuriyet, 22 Aralık 1930). Atatürk'ün izlenimlerine göre halkın en büyük sıkıntısı düşen ürün fiyatlarıdır (Milliyet, 22 Aralık 1930). Ancak, Atatürk'ün izlenimlerine göre Kırklareli Halkı halkçılık ve devletçilik ilkelerini çok iyi anlamıştır (Goloğlu, 2017: 300). Türkmen'in ifadesine göre toplantı 4,5 saat sürmüş olup Gazi Kırklareli'ye geldiğinde CHF İl Başkanı olan Avukat Tahir Taner Bey SCF'den seçimde aday olduğu için il başkanlığı görevine vekaleten bakılmaktayd. Gazi Mustafa Kemal, seçimler üzerine uzun uzun konuşmalar ve tartışmalar yapmıştır. Toplantı esnasında Halk Fırkası binasından ayrılan İç İşleri Bakanı Şükrü (Kaya) 
Bey postaneye geçerek Atatürk'ün CHF'nin 1930 Belediye Seçim sonuçlarını eleştirdiği yönünde Başvekil İsmet (İnönü) Bey’e telgraf çekmiştir (Görünüm, 21 Aralık 2017). Toplantıda Atatürk Kırklareli'de dört belediye kazanan SCF teșkilatından Tahir Bey, Avukat Mehmet Bey, Diş Doktoru Halit Bey, Hasan Bey ve Mustafa Arif Bey ile de görüşüp kendilerini tebrik etmiştir (Karaçam, 1969: 37; Pınar, 2016: 29). Bu dönemde CHP taşra siyaseti incelendiğinde, Tek Parti yönetimi ve onun üst düzey bürokratlarıyla kişisel çıkar ilişkileri olan ve geleceğe dönük kariyer planları bulunan taşra elitlerinin tekelinde toplanmıştır. Bu da partinin halktan kopuk dar bir kulvarda siyaset yapmasına tabanın sesini duyamamasına neden olmuştur (Aydemir, 1999: 365; P1nar, 2016: 118).

Atatürk'ün memurların halka olan kötü tavırlarını duyması üzerine 20-22 Aralık 1930 tarihinde Kırklareli ilinde verdiği demeçte devlet mekanizmasının mükemmel işlemesi ve halka iyi davranılması gerektiği konusunda bilgiler vermiştir. Halkın bürokratlarla ilgili şikayetlerini de bildirmelerini istemiştir. CHF'nin Trakya'daki ataletine karşı firka prensiplerinin herkese açıkça anlatılmasını istemiştir (Milliyet, 22 Aralı 1930).

1929 yılındaki krizin etkisiyle tarımsal ürün fiyatlarının hızla düşmesi pazara yönelik üretim yapan Batı Anadolu, Çukurova ve Trakya'da birçok köylüyü ve tüccarı iflasa sürüklemiştir. Tarımdaki kazançların düşmesi kentlerde mamul maddelere olan talebi de düşürmesiyle iflas toptan toplumun farklı kesimlerini etkilemiş̧ir (Pamuk, 2015: 186). Ancak SCF'nin kuruluşundan sonra halk haklı haksız bazı şikayetlerini dile getirmeye başlamıştır. Örneğin Atatürk'ün treninin Kırklareli'ye hareket etmek üzere Alpullu istasyonundan ayrıldığı bir esnada yüksek sesle seslenen bir kişi köylüye bakılmasını çiftçinin borç içinde olduğunu kendisinin de tüm hayvanlarını sattığını ifade etmiştir. Ancak yapılan araştırma sonucu bu yurttaşın epey hayvan sahibi bir tüccar olduğu anlaşılmıştır (BCA 49010034142 1). Neticede Kırklareli özelinde yaşanan tüm bu gelişmeler Atatürk'e halkın toplumsal ve iktisadi konularda rejime yönelik ne gibi tepkiler verdiğini göstermiştir. 1929 Dünya İktisadi Buhranı ortamında liberal ekonomi politikalarının başarılı olamayacağını ve devletçiliğin gerekli olduğunu da kanıtlamıştır.

\section{Sonuç}

Serbest Cumhuriyet Fırkası'nın Trakya Bölgesi'ndeki kuruluş ve örgütlenmesi üzerine literatürün görece daha sınırlı olduğu görülmüştür. Bu çalışma SCF'nin Kırklareli Teşkilatlanması ve 1930 Belediye Seçimlerine, iktisat, tarih, coğrafya ve Türk Dış Politikasını 
da içeren disiplinler arası bir perspektifle yaklaşırken hem devlet adamlarının raporlarını hem de sıradan insanların yaşam deneyimlerini ve kırsalı da dikkate alarak bütüncül bir bakış açısı ile Türk Demokrasi Tarihine katkıda bulunmaya çalışmıştır. Nitekim 1878-1922 yılları arasında yaklaşık yarım asırdır, sınırların sık sık değiştiği ve demografik hareketliliğin olduğu Trakya, 1920'lerin ve 1930'ların toplumsal ve iktisadi sorunları kadar Birinci Dünya Savaşı'nın sonuçlarının neden olduğu Bulgaristan kaynaklı tehditlere maruz kalmıştır. Tüm bunlar, Trakya'da iç ve dış politikayı birlikte düşünmeyi gerekli kılmıştır. Ayrıca, Trakya içinde de Kırklareli ilinin araştırmaya konu edilme nedeni ise Kırklareli ilinin Edirne ve Tekirdağ'a oranla ekonomik açıdan daha geri kalmış olması ve 1930 Belediye Seçimlerinde SCF'nin il genelindeki yüksek başarısıdır.

$\mathrm{Bu}$ seçimlerde Kırklareli halkı her ne kadar Bulgar tehlikesi karşısında yaşadıkları gelecek endişesi, Yahudilerin piyasaların tamamına yakınına hakim olan sermayeleri karşısında yaşadıkları ekonomik y1lgınlık, göçün neden olduğu iskan ve tapu sorunları, 1929 Ekonomik Buhranının yaşandığı bir dönemde ve Trakya geneline oranla daha dağlık bir bölgede yaşadıkları daha zor geçim şartlarında SCF'yi desteklemiş olsalar da Tek Parti iktidarının temel hedefinin 1925 yılı sonrasinda yapılan devrimlerin ve iktisadi kriz ortamında halkın tepkisini ölçmek hedefinde olduğu görülmektedir. Bir diğer açıdan da ulus devletin temellerinin atıldığı ve uluslararası alanda da iki savaş arası dönemde kıta Avrupa'sında totaliter tek parti yönetimlerinin olduğu bir evrede, çok partili yaşama geçiş denemesi bir ölçüde, liberal ilkeleri savunan bir parti üzerinden öncelikle liberal ekonomi fikirlerinin meşruiyetini halk nezdinde sarsmanın ve 1930'larda gerçekleştirilecek olan devletçi politikaları meşrulaştırmanın bir ön çalışmasıdır. Nitekim çok partili yaşama geçmek için ne taşrada tam bir demokrasi bilinci vardı ne de rejimin yeni kurulduğu bir ortamda üstelik de TpCF deneyiminin üzerinden henüz beş yıl geçtiği bir dönemde demokratikleşmeye izin verebilecek bir Tek Parti iktidarı vardı. Tüm bunların olmadığını seçimlerdeki usulsüzlüklerden ve SCF' nin kapatılmasından da anlamak mümkündür.

SCF'nin Kırklareli ilindeki başarısında CHF teşkilatlarının bir toplum ve siyaset mühendisliğiyle toplumdan kopuk siyaset üretmeleri ve partinin Kırklareli il teşkilatında ve Belediyelerinde partililer arasında yaşanan bölünmeler ve hizipçilik de etkili olmuştur. CHF teşkilatları, taşranın önde gelen ailelerinin çıkar çatışmalarını ve şahsi menfaatlerini korumak için siyaset yaptıkları bir alana dönüşmüştür. Ayrıca, 1930 Belediye Seçimlerinde Kırklareli ilinde üst düzey bürokrat ve milletvekillerinin de karıştıklarının iddia edildiği seçim 
usulsüzlükleri parti teşkilatlarının seçmenle olan alakasını ve zayıf bağlarını da ortaya koymuştur.

Kurklareli ili genelinde SCF'ye en büyük destek iskân ve tapu sorunu yaşayan göçmenlerden, 1929 Ekonomik krizi ortamında ürünlerini değer fiyatından pazarlayamayan köylüden ve devletçilik karşısında bölgedeki tekellerini kaybetme endişesi yaşayan Yahudilerden gelmiştir. Kırklareli Belediyesi CHF ve Lüleburgaz Belediyesi SCF tarafından az bir oy farkıyla kazanılmış olsa da kırsal nüfusun ağırlıklı olduğu Üsküp, Pınarhisar ve Vize Belediyeleri \%70 ile $\% 90$ arası oy oranlarıyla SCF tarafından kazanılmıştır. Ancak 17 Kasım 1930 tarihinde SCF'nin kapatılmasından sonra verilen bu demokratik desteğin bir önemi kalmamış ve Tek Parti buradan hareketle Kırklareli iline yönelik neler yapması gerektiğini planlamıştır. $\mathrm{Bu}$ kapsamda, Atatürk'ün Kırklareli iline 20 Aralık 1930 tarihinde bir ziyaret gerçekleştirmesi, 1934 yılında Trakya Umumi Müfettişliğinin Kurulması, 1934 Trakya Olaylarında sermeyenin el değiştirmesi ve 1939 yılında Kepirtepe Köy Enstitüsü'nün Kırklareli ili Lüleburgaz İlçesinde kurulması gerçekleştirilmiştir.

\section{Kaynakça}

Başbakanlık Cumhuriyet Arşivi, [BCA], 490017284781 (CHP Müfettiş Raporlar1-Kırklareli İline Ait K1sım).

Başbakanlık Cumhuriyet Arşivi, [BCA], 490100341421 (Atatürk'ün Seyahat Notlar1-17.11.1930).

T.C Türkiye Büyük Millet Meclisi, TBMM Zabıt Ceridesi, 3. Dönem 22. Cilt 5. Birleşim, (15.11.1930).

T.C. Devlet İstatistik Enstitüsü. (1937). Genel Nüfus Sayımı Kati ve Mufassal Neticeleri Kirklareli Vilayeti (1935). İstanbul: Hüsnütabiat Basimevi.

T.C Devlet İstatistik Enstitüsü (DİE). (1970). Tarım Sayımı (1927). Ankara: DİE Matbaas1.

T.C Başbakanlık İstatistik Direktörlüğü. (1936). Tarım Istatistikleri (1928-1934). Ankara: Ulus Basimevi.

Aysal, N. ve Dinçer, H. (2020). Türkiye'nin Sihhî ve İçtimaî Coğrafyası Raporlarına Göre: Kirklareli. Mavi Atlas, 8(2), 235-255.

Aydemir, Ş. S. (1999). Tek Adam Mustafa Kemal 1922-1938 III. İstanbul: Remzi Kitabevi.

Burgaç, M. (2017). Trakya Raporu (1934). Ankara: Kaynak Yayınları.

Ceylan, O. (2021). Serbest Cumhuriyet Fırkası'nın Edirne Serüveni: Türkiye Demokrasi Tarihinden Notlar. Çăgdaş Türkiye Tarihi Araştırmaları Dergisi, 21(42), 269-294. 
Çavdar, T. (2008). Türkiye'nin demokrasi Tarihi. Ankara: İmge Kitabevi.

Doğruöz, T. (2003). Yakın Dönem Kırklareli Tarihinde İki Yaprak: Trakya'da Yeni Işık Gazetesi ve İzmir Suikastını Tel'in Mitingi. Yakın Dönem Türkiye Araştırmaları Dergisi, (4), 4360.

Engin, V. (2008). Rumeli Demiryolu. Türkiye Diyanet Vakfi İslam Ansiklopedisi içinde (Cilt. 35, ss. 236-237).

Ivanova, M. (1978). Les Luttes Politiques en Turquie 1924-1930. Etudes Balkanique, (4), 12-31.

İnönü, İ. (1998). Cumhuriyet'in Illk Yllları I (1923-1938), İsmet İnönü'nün Hatıraları. İstanbul: Cumhuriyet.

Goloğlu, M. (2017). Türkiye Cumhuriyeti Tarihi -I Devrimler ve Tepkiler. İstanbul: Türkiye İș Bankası Yayınları.

Karaömerlioğlu, M. A. (2006). Orada Bir Köy Var Uzakta. İstanbul: İletişim.

Karaömerlioğlu, M. A. (1999). The People's Houses and the Cult of the Peasant in Turkey. Sylvia Kedourie (Ed.), Halkevleri ve Türkiye'de Köylü Kültü, Turkey Before and Before Atatürk içinde (s. 67-91). London, Frank and Cass.

Karaömerlioğlu, M. A. (1998). Köy Enstitüleri Üzerine Düşünceler. Toplum ve Bilim, (76), 56-85.

Karaçam, N. (1969). 20 Aralık 1930 Atatürk Kırklareli'nde. İstanbul: Okay Yayınları.

Keyder, Ç. ve Birtek, F. (2016). Türkiye'de Devlet -Tarım İlişkileri (1923-1950). Çağlar Keyder (Ed.), Toplumsal Tarih Çalışmaları. İstanbul: İletişim.

Koçak, C. (2011). Tek Parti Döneminde Muhalif Sesler. İstanbul: İletişim.

Koçak, C. (2006). Belgelerle İktidar ve Serbest Cumhuriyet Furkası. İstanbul: İletişim Yayınları.

Mazlum, G. (2020). Atatürk'ün Trakya Gezisi ve Edirne Anıları. Edirne: Edirne Belediyesi Yayınlar1.

Osman, O. ve Seydanlıŏlu, M. (2006). Atatürk, Okyar ve Çok Partili Türkiye. Ankara: Türkiye İş Bankası Kültür Yayınları.

Özey, R. (2002). 19. Asırda Edirne Vilayeti Coğrafyası. Marmara Coğrafya Dergisi, (6), 1-36.

Pamuk, Ş. (2015). Türkiye’nin 200 Ylllık İktisadi Tarihi. İstanbul: İş Bankası Kültür Yayınları.

Pınar, M. (2016). Tek Parti Döneminde Trakya'da Siyasi Hayat ve Yahudiler (1930-1934). Ankara: Grafiker. 
Tekeli, İ. ve İlkin, S. (1977). 1929 Dünya Buhranında Türkiye’nin İktisadi Politika Arayışları. Ankara: ODTÜ.

Timur, T. (1997). Türk Devrimi ve Sonrast. Ankara: İmge.

Toprak, Z. (2020). Atatürk Kurucu Felsefenin Evrimi. İstanbul: Türkiye İş Bankası Kültür Yayınları.

Toprak, Z. (2004). Türkiye'de Sol Faşizm ya da Otoriter Modernizm 1923-1946. Toplum ve Bilim, (100), 84-99.

Toprak, Z. (2003). 80. Yı1dönümünde Lozan Barış Antlaşması. Toplumsal Tarih, (115), 64-71.

Tuncay, M. (1999). Türkiye Cumhuriyeti’nde Tek Parti Yönetiminin Kurulması (1923-1931). İstanbul: Tarih Vakfı Yurt Yayınları.

Yavuz, E. (2018). Sihhat ve İçtimaî Muavenet Vekâletinin 1924 Y11 Sitma ile Mücadele Raporu- Sitma ve Bataklık Haritası. Journal of Social and Humanities Sciences Research, 5(19), 235-255.

Zurcher, E. J. (2000). Modernleşen Türkiye'nin Tarihi. Yasemin Saner Gönen (Çev.). İstanbul: İletişim Yayınları.

Cumhuriyet

Edirne Millî Gazete

Edirne Postasl

Görünüm

Hakimiyet-i Milliye

Hürriyet

Milliyet

Son Posta

Vakit 